Наталии Ионовне (она тоже была всю жизнь преподавательницей, а позднее получила почетное звание заслуженной учительницы Российской федерации) Цомак просил: «Потом опять о детском саде... Еще раз сходи: узнай литературу о детском саде и напиши. Это одно. Потом, Наточка, наверное, там есть детские площадки. Узнай, как используют детские площадки... Как организуются игры и пр. Все, все... И свои впечатления... Еще, если можно, литературу о детских играх, об их организации» [4].

Сказанное позволяет прийти к следующему размышлению: детство представлено в произведениях Ц.Гадиева не как «счастливая пора», время беззаботных игр, когда все потребности ребенка спешат быть удовлетворенными заботливыми родителями, но как время тяжелое, наполненное страданием и необходимостью принимать сложные нравственные решения.

Знакомство с произведениями Ц.Гадиева имеет большую педагогическую ценность. Они призваны в самих детях развить чувства участия, сострадания, внимательности по отношению друг к другу. Автор в своем творчестве развивает идею о том, что общество не может быть названо справедливым, гуманным до тех пор, пока в нем есть хоть один ребенок, лишенный детства. Хоть один, вынужденный страдать. И сегодня, в XXI веке эти идеи не теряют своей актуальности.

$$
* * *
$$

1. Ардасенов Х.Н. Очерк развития осетинской литературы. Орджоникидзе, 1959. - 342 с.

2. Гугкаева И.Т. Видный просветитель Северного Кавказа М.Ю.Гадиев о проблемах воспитания. // Вестник Поморского университета. Серия « Гуманитарные и социальные науки». Выпуск 9/ 2007. C.135-137.

3. Гадиев Ц. Избранные сочинения (на осетинском языке). Орджоникидзе: Северо-Осетинское книжн. изд. 1959, 176 с.

4. Гадиев Ц. Вопросы народного образования среди горцев // Коммунист, 1953, 27 апреля, № 16.

5. Джикаев Ш. Поэт и гражданин (К 90-летию со дня рождения Цомака Гадиева) // Литературная Осетия, 1972, № 40, С.93.

6. Джусоев Н. Цомак Гадиев // Очерк истории осетинской современной литературы. - Ордзоникидзе, 1967. - $406 \mathrm{c}$.

7. Цховребова Л. Э. Жизнь и творчество Ц. Гадиева и русская литература. - Сталинир, 1961. - 298 с.

8. Кантемирова Р. Тема детства в творчестве Ц.Гадиева / // Ираф.- 2009.- № 2.- Ф. 246-253.

9. Кабулова Г.С. Тема детской судьбы в произведениях А.Н. Плещеева И К.Л. Хетагурова. Московский экономический журнал. 2016. № 3. С. 20.

10. Кабулова Г.С. Проблема деградации личности в произведениях А.П. Чехова И А.Б. Коцоева. Балтийский гуманитарный журнал. 2015. № 4 (13). С. 74-77.

\title{
Лисевская А.И., Титаренко Н.В. \\ Специфика глагольных форм древнеиспанского языка (на материале «Cantar de mio Cid» XII)
}

ФГБОУ ВО «Волгоградский государственный социально-педагогический университет» doi: 10.18411/lj-04-2021-195

(Россия, Волгоград)

\section{Аннотация}

В статье обозначены понятия глагола и глагольных форм на основе анализа литературы по теме исследования, рассмотрены глагольные формы древнеиспанского языка, проведен анализ глагольных форм древнеиспанского языка (на материале «Cantar de mio Cid»)

Ключевые слова: глагол, глагольные формы, переходность, наклонение, залог, вид, время, спряжение.

\section{Abstract}


The article marks the concepts of the verb and verb forms based on the analysis of the literature on the topic of the study, examines the verb forms of the Old Spanish language, analyzes the verb forms of the Old Spanish language (based on the material «Cantar de mio Cid»)

Keywords: verb, verb forms, transitivity, mood, voice, aspect, tense, conjugation.

Наша статья посвящена глагольным формам древнеиспанского языка, а именно их специфике на материале испанского героического эпоса XII века «Cantar de mio Cid». Изучением данной темы занимались такие ученые как: Р. Менендес Пидаль, В.П. Григорьев, М. Торрес Альварес и др.

Испанский язык является романским языком т.е языком, основы которого были заложены латинским языком. С течением времени он постепенно изменялся и преобразовывался. Для того чтобы проследить эволюцию испанского языка, нами были проанализированы глагольные формы в героическом эпосе XII века «Cantar de mio Cid».

Для начала необходимо прояснить, что из себя представляет глагол, глагольные формы и то, какие изменения в них произошли с течением времени. Для этого мы поставили следующие задачи:

1) обозначить понятия глагола и глагольных форм на основе анализа научной литературы по теме исследования;

2) рассмотреть специфику глагольных форм древнеиспанского языка;

3) провести анализ глагольных форм древнеиспанского языка (на материале «Cantar de mio Cid».

Изучая литературу по заявленной теме, мы встречаем различные определения глагола, тем не менее большинство испанских грамматистов придерживается определения глагола, данного Грамматической Испанской академией: «Глагол - это часть речи, которая обозначает состояние, действие или восприятие действия, почти всегда с выражением времени и лица» [Diccionario de la lengua española RAE, 2014].

В современном испанском языке глагол представляет собой сложную систему многочисленных форм. Все глагольные формы имеют характеристики залога, возвратности, переходности. Личные формы изменяются по наклонениям, временам, лицам, числам.

В испанском языке глагол имеет следующие показатели:

1. Переходность;

2. Наклонение;

3. Залог;

4. Вид;

5. Время;

6. Спряжение.

Следуя логике нашего изложения, считаем необходимым провести анализ изменений глагольных форм с течением времени.

Для проведения анализа следует сравнить глагольную форму в латинском языке, в литературном источнике и современном испанском. В качестве литературного источника для анализа глагольных форм было взято произведение: «Cantar de mío Cid». «Cantar de mío Cid»- это героический эпос, написанный после 1195, но до 1207 года анонимом. Она повествует о доблестном герое Сиде, который борется против мавров и освобождает от них родные земли. Данное произведение является классическим героическим эпосом.

В испанском языке очень употребляемым является глагол ir - идти, который в латинском имеет форму - īre.

B «Cantar de mío Cid» данный глагол тоже присутствует:

Esta noch yagamos vayamosnos al matino, 
ca acusado sere de lo que vos he servido;

В испанском и в латинском языках, данный глагол является непереходным, он не может образовать страдательный залог, поэтому строчка из «Cantar de mio Cid», является примером активного залога, кроме того, ir является глаголом индивидуального спряжения. Vayamos в современном испанском является формой Presente de Subjuntivo, первого лица множественного числа, уже в своей современной форме.

Nonbrados son los que iran en el algara,

e los que con Mio Çid ficaran en la çaga

Другой пример показывает форму глагола $\mathrm{Ir}$, которая близка к современной и форме Futuro de Indicativo. В современном варианте испанского над буквой а стоит ударение (irán). В этом примере глагол находится в форме третьего лица множественного числа в форме Futuro de Indicativo, в активном залоге.

A terçer dia dados fueron sin falla.

Глагол ir находится уже в современной форме Pretérito indefinido de Indicativo также в форме третьего лица множественного числа, в активном залоге. В испанском языке весьма часто используется глагол decir - говорить. Он также произошёл из латинского языка. Однако к моменту написания «Cantar de mío Cid» он ещё не приобрёл современную глагольную форму. Например:

«Plazme», dixo el Çid, «D’aqui sea mandada;

В латинском языке форма 3-го лица perfecto имеет форму dīxit, а первого dīxī. Формы Presento в латинском 1-го и 3-го лиц dīcō и dīcit. Можно заметить, что форма dixо это уже не латынь, но ещё не современный вариант испанского dijo, тем не менее он становится близок к нему. Decir произошёл от латинского dicĕre.

Предположительно, что diхо является формой Pretérito indefinido de indicativo, также как и форма в современном испанском языке dijo. Глагол в данном случае принадлежит к наклонению Indicativo. Переходные глаголы могут образовывать пассивный залог, но в примере из «Cantar de mío Cid» dixo это глагол в активном залоге. В современном испанском decir - это глагол третьего спряжения, но в некоторых временных формах он является неправильным. Глагол стоит в форме единственного числа, третье лицо.

Ещё один глагол это глагол ver - видеть. Глагол ver произошёл от латинского vidēre. Однако в латинском языке форма будущего времени множественного числа имеет videbimus

en San Pero de Cardenna i nos cante el gallo;

veremos vuestra mugier menbrada fijadalgo;

Yo lo veo que estades vos en ida

e nos de vos partir nos hemos en vida:

В строчках из «Cantar de mío Cid», видно, что глагол ver имеет современную форму Futuro de Indicativo. Тем самым мы видим, что уже в древнеиспанском глагол приобретает своё современное спряжение. Ver - это переходный глагол, представленный в данном случае в форме Futuro de Indicativo, первого лица множественного числа. Veremos - это форма активного залога. Ver - глагол индивидуального спряжения.

El rrey lo ha vedado, anoch del entro su carta

con grant rrecabdo e fuertemientre sellada.

В данном примере мы можем видеть почти современную фору глагола ver в Pretérito Perfecto, однако в Pretérito Perfecto de Indicativo глагол ver имеет неправильную форму visto. Данный глагол представлен в форме третьего лица, единственного числа, в активном залоге. Глагол abrir - в древнеиспанском приобрёл свою современную форму. Он произошёл от латинского aperīre 
В «Cantar de mío Cid» есть строчки с этим глаголом

abrio sos ojos, cato a todas partes,

Данная форма похожа на современную форму Pretérito Indefenido de Indicativo. Тот же самый глагол в прошедшем времени в латинском языке aperuit. Глагол abrir является переходным глаголом, третьего спряжения. В данном предложении глагол употреблён в активном залоге, в форме третьего лица единственного числа.

Dixo Martin Antolinez: «Vere a la mugier a todo mio solaz,

castigarlos he commo abran a far.

В вышепредставленном примере глагол abrir находится в современной форме Presente de Subjuntivo в третьем лице множественного лица, в активном залоге. Глагол saber - знать произошёл из народной латыни от глагола sapēre, который в свою очередь известен в латыни как sapere.

В староиспанском варианте глагол saber ещё не совсем похож своей глагольной формой на современный вариант испанского. Однако, сходство является очевидным. Например:

e a todas sus duennas que con ellas estan;

bien sepa el abbat que buen galardon d'ello prendra.

Sapit это латинская форма 3-го лица единственного числа настоящего времени. Форма глагола, которая приведена в качестве примера из «Cantar de mío Cid», это современный вариант Presente de Subjuntivo в третьем лице, единственном числе. Глагол saber является переходным глаголом. В данном случае, глагол употреблён в активном залоге. Saber является глаголом индивидуального спряжения.

Bien lo sabemos que el algo ganno,

quando a tierra de moros entro que grant aver saco;

non duerme sin sospecha qui aver trae monedado.

Здесь мы видим глагол saber уже в своей современной глагольной форме Presente de Indicativo первого лица множественного числа, в активном залоге.

El Çid a donna Ximena ivala abraçar,

donna Ximena al Çid la mano l' va besar,

lorando de los ojos que non sabe que se far.

Здесь глагол seber находится в современной форме Presente de Indicativo, третьего лица единственного числа, в активном залоге.

Такой глагол как pasar также произошёл из латинского языка. В народной латыни глагол был с удвоенной буквой -s passāre, а в латинском passum. Также и в Сиде глагол pasar употребляется с сохранившейся двойной буквой $-\mathrm{s}$

«iTemprano dat çebada, si el Criador vos salve!

El que quisiere comer; e qui no, cavalge.

Passaremos la sierra que fiera es e grand;

В современном испанском это форма Futuro Simple de Indicativo. Pasar - это переходный глагол. В данном примере, он находится в активном залоге. Pasar правильный глагол первого спряжения. Pasaremos - в современном испанском является формой первого лица и единственного числа.

Martin Antolinez non lo detardava,

passo por Burgos, al castiello entrava,

В данном примере глагол pasar напоминает современную форму прошедшего времени Indefenido de indicativo pasó в третьем лице, единственного числа, активный залог

Глагол ser является одним из самых важных и часто употребляемых в испанском языке. В латинском это глагол sum. Современный вариант испанского ser восходит к древнеиспанскому seer. На основании строчек из «Сantar de mío Cid» можно 
проанализировать, что уже во время написания данного произведения глагол ser приобрёл свою современную форму.

El Campeador por las parias fue entrado, grandes averes priso e mucho sobejanos; rretovo d'ellos quanto que fue algo, por en vino a aquesto porque fue acusado. « YYa Canpeador en buen ora çinxiestes espada! De Castiella vos ides pora las yentes estrannas; assi es vuestra ventura, grandes son vuestras ganançias, una piel vermeja morisca e ondrada Çid, beso vuestra mano en don que la yo aya.»

В современном испанском глагол ser является вспомогательным глаголом. Также, как и глагол ir он является непереходным. В вышеперечисленных примерах наклонение Indicativo. Глагол ser используется для формирования пассивного залога, однако в «Cantar de mío Cid» он употребляется в активном залоге. Fue - это временная форма глагола в третьем лице единственном числе в Pretérito indefinido de indicativo, a форма son- это форма третьего лица, множественного числа presente de indicativo.

Espeso é el oro e toda la plata;

bien lo vedes que yo no trayo nada,

e huebos me serié pora toda mi companna.

Con vuestro consego bastir quiero dos archas;

incamoslas d'arena ca bien serán pesadas,

cubiertas de guadalmeçi e bien enclaveadas.

В данных примерах глагол ser имеет тоже наклонение Indicativo, и можно предположить, что это время Futuro simple, так как serié является формой первого лица единственного числа, a serán является формой третьего лица множественного числа.

Mio Çid Ruy Diaz el que en buen ora çinxo espada

poso en la glera quando no l' coge nadi en casa,

derredor del una buena conpanna.

Assi poso Mio Çid commo si fuesse en montanna.

Также в данном произведении мы можем заметить, конструкцию с использованием сото si. Здесь употреблена форма Imperfecto de Subjuntivo, но данная форма отличается от современного варианта fuera.

Pensemos de ir nuestra via, esto sea de vagar.

Данный глагол представлен в форме Presente de Subjuntivo в третьем лице единственного числа в активном залоге.

Для сопоставления было выбрано несколько глаголов, которые были проанализированы и сопоставлены с латинским вариантом и с современным вариантом данного глагола в испанском.

В заключении следует сказать, что достаточно много глаголов из «Cantar de mío Cid» уже приобрели свой современный вариант в той или иной форме.

Некоторые глаголы в данном произведении остались с некоторыми особенностями из латинского языка, однако они довольно похожи на современную форму того или иного времени.

\section{$* * *$}

1. Васильева-Шведе О.К., Степанов Г.В. Теоретическая грамматика испанского языка: Морфология и синтаксис частей речи. - М.: Высшая школа, 2003. 387 с

2. Гурычева М.С. Народная латынь., М.: Издательство литературы на иностранных языках, 1959. 190 c. 
3. Cantar de mio Cid / Anónimo; edición, presentación, estudio y notas de Alberto Montaner; con un ensayo de Francisco Rico; ensayo introductorio de Margit Frenk, 2014. 1200 p. — (Clásicos de la Lengua Española)

4. Diccionario de la Real Academia Española [DRAE] [Электронный pecypc] URL: https://dle.rae.es/?w=diccionario\&origen=REDLE (дата обращения: 27.02.2021)

\section{Осташевская Е.Ю. \\ Перцептивная лексика английского языка с семантическим компонентом «теплота» в рекламном тексте}

Самарский государственный соџчильно-педагогический университет (Россия, Самара)

doi: 10.18411/lj-04-2021-196

\section{Аннотация}

В статье рассматриваются особенности функционирования английской перцептивной лексики с семантическим компонентом «теплота» в рекламных текстах. Используется обширный материал, представленный рекламными объявлениями различных товаров, мероприятий, услуг. На основе анализа словарных дефиниций устанавливаются значения, актуализируемые в целях создания у потребителя приятных температурных ощущений и эмоций, способствующих выполнению рекламным текстом функции воздействия и повышению его прагматического потенциала.

Ключевые слова: восприятие, температурное ощущение, реклама, воздействие, семантика, теплота

\section{Abstract}

The article examines the peculiarities of the English perceptual vocabulary with the semantic component "warmth" in advertising texts. The research involves extensive material represented by advertisements of various products, events, and services. On the basis of the analysis of dictionary definitions, the author finds out meanings that are realized in order to create pleasant temperature feelings and emotions in the consumer, which contribute to the performance of the persuasion function by the advertising text and increase its pragmatic potential. warmth

Key words: perception, temperature sensation, advertising, impact, semantics, heat,

Возникновение и развитие рекламы большинство ученых связывают с развитием массовой коммуникации, порождённой, в свою очередь, урбанизацией [1]. Среди особенностей рекламы в первую очередь отмечают ее общественный характер.

Т. Лившиц полагает, что реклама есть сообщение, целью которого является побуждение реципиента к ответным действиям [2]. Ф.Котлер считает, что реклама выполняет несколько функций: информативную, увещевательную и напоминающую [3]. Чтобы выделиться в океане рекламы, бренды создают полезный контент, отвечающий новым потребностям покупателей [4].

Определение рекламы как особого типа текстов связано со сложностями, возникающими в результате ее многоплановости и неоднозначности. Реклама, для того чтобы воздействовать, мотивировать определенное действие со стороны читателя (приобретение товара или услуги), должна передавать некое содержание, или «идею», выходящую за пределы метасемиотического уровня [5].

Как известно, основными функциями языка являются сообщение определенной информации и воздействие на адресата сообщения. Для рекламных текстов главной является функция воздействия [5], поэтому необходимо очень хорошо представлять себе потенциального покупателя, учитывать вкусы и привычки человека, чтобы 